\title{
PENGARUH SUBSTITUSI TAHU DAN VARIETAS NANGKA MUDA TERHADAP KARAKTERISTIK KIMIA DAN SENSORIS DENDENG TAHUNA
}

\section{EFFECT SUBSTITUTION OF TOFU AND YOUNG JACKFRUIT VARIETIES ON CHARACTERISTICS OF CHEMICAL AND SENSORY OF TAHUNA JERKY}

\author{
Ramadhani Sofika Azaka $^{1)}$, Enny Sumayati ${ }^{1)}$, Suprihana ${ }^{1)}$ \\ ${ }^{1)}$ Teknologi Hasil Pertanian, Fakultas Pertanian, Universitas Widyagama Malang \\ Email: ramadhanisofika22@gmail.com
}

\begin{abstract}
ABSTRAK
Dendeng merupakan makanan berbentuk lempengan yang telah diberi bumbu dan dikeringkan. Salah satu produk dendeng nabati yaitu berbahan dasar nangka muda dan tahu. Keunggulan dendeng TAHUNA meliputi, kandungan protein dan serat pangan (dietary fiber). Tujuan penelitian ini adalah untuk mengetahui pengaruh substitusi tahu dan jenis nangka muda terhadap karakteristik dendeng TAHUNA yang dihasilkan. Penelitian menggunakan 2 faktor yang disusun secara faktorial menggunakan Rancangan Acak Kelompok (RAK). Faktor pertama adalah varietas nangka muda yaitu nangka salak dan nangka bubur. Faktor kedua adalah proposi tahu yang terdiri dari 3 level yaitu 0\%, 20\%, 40\%. Masing-masing perlakuan diulang tiga kali. Hasil penelitian menunjukkan kadar air 14,3\%-22,3\%, kadar serat 5,05\%-11,9\%, kadar protein 4,56\%-14,46\%, kadar abu 5,11\%-6,57\% dan nilai organoleptik rasa 3,1\%-3,6\%, warna 3,3\%-4\%, aroma $3,8 \%-4,3 \%$, tekstur 3,8-4,3\%. Hasil analisa statistik menunjukkan varietas nangka muda memberikan pengaruh nyata terhadap kadar air, kadar serat, kadar protein. Proporsi tahu memberikan pengaruh nyata terhadap kadar air, kadar serat, kadar protein, kadar abu dan organoleptik aroma dan tekstur. Interaksi kedua faktor berpengaruh terhadap kadar serat dan kadar protein.
\end{abstract}

Kata Kunci: dendeng, nangka muda, tahu

\section{ABSTRACT}

Jerky is food in the form of slabs that have been seasoned and dried. One vegetable jerky product is made from young jackfruit and tofu. The advantages of TAHUNA jerky are the ingredients which contain protein and fiber content (dietary fiber). The purpose of this study was to determine the effect of substitution of tofu and young jackfruit types on the characteristics of TAHUNA jerky produced. This study uses 2 factors that were arranged in factorial using Randomized Block Design (RBD). The first factor was young jackfruit. The second is the proportion of tofu which consists of 3 levels, namely 0\%, 20\%, 40\%. Each treatment was repeated three times. The results showed that water content of the jerky was 14.3\%-22.3\%, fiber content was 5.05\%-11.9\%, protein content was $4.56 \%-14.46 \%$, ash content was 5,11\%-6,57\% and organoleptic value of 
taste was 3.1\%-3.6\%, color was 3.3\%-4\%, aroma was $3.8 \%-4.3 \%$, and the texture was 3.8\%-4.3\%. The results of statistical analysis showed that young jackfruit varieties had significant effect on water content, fiber content, and protein content. Proportion tofu has a significant influence on water content, fiber content, protein content, ash content, organoleptic aroma, and texture. The interaction of the two factors affected fiber and protein content.

Keywords : jerky, young jackfruit, tofu

\section{PENDAHULUAN}

Dendeng

merupakan

makanan yang berbentuk lempengan yang terbuat dari irisan atau gilingan daging segar berasal dari sapi sehat yang telah diberi bumbu dan dikeringkan (SNI 01-2908-1992). Kesadaran masyarakat akan kandungan lemak dan kolesterol dari produk hewani dan berbahaya bagi kesehatan membuka peluang menciptakan produk dendeng nabati. Salah satunya adalah nangka muda sebagai bahan dasar pembuatan dendeng.

Nangka muda merupakan salah satu sayuran yang banyak tumbuh di Indonesia. Menurut Direktorat Gizi Depkes RI (1981) kandungan gizi nangka muda per100 gram adalah kalori (kal) 51,00, protein (g) 2,00, lemak (g) 0,40, karbohidrat (g) 11,30, kalsium (mg) 45,00, fosfor (mg) 29,00, zat besi (mg) 0,50, vitamin A (SI) 25,00, vitamin B1 (mg) 0,07, vitamin C (mg) 9,00 dan air (g) 85,40. Keunggulan dendeng nabati berbahan dasar nangka muda ini terdapat pada kandungan serat pangannya (dietary fiber). Akan tetapi nangka muda mengandung sedikit protein sehingga alternatif pemecahannya adalah dengan melakukan fortifikasi protein dengan penambahan tahu kedelai.

Tahu merupakan salah satu bahan pangan yang secara tradisional telah dikenal bangsa Indonesia turun temurun. Tahu mengandung protein tinggi yang berpotensi sebagai sumber fortifikasi. Perlu dilakukan penelitian untuk mengetahui formulasi yang tepat dalam pembuatan dendeng dan mengkaji sampai sejauh mana pengaruh substitusi penambahan tahu dan varietas jenis nangka muda terhadap karakteristik kimia dan sensoris dendeng TAHUNA. Serta mengkaji 
respons panelis terhadap produk dendeng dari nangka muda yang sebagian bahan bakunya telah disubstitusikan dengan tahu.

\section{METODE PENELITIAN}

\section{Bahan dan Alat}

Bahan yang digunakan adalah nangka muda (varietas nangka bubur dan nangka salak) dari pasar Dinoyo Malang, tahu dari home industri Raja Tahu di Perumahan Tidar, bawang putih, ketumbar, jinten, cabe merah, daun jeruk purut, gula jawa, garam dan asam jawa. Sedangkan bahan untuk analisa antara lain pelarut organik, asbes, aquades, $\mathrm{NaOH}$, $\mathrm{H}_{2} \mathrm{SO}_{4}, \mathrm{~K}_{2} \mathrm{SO}_{4}$, alkohol 95\%, tablet Kjeldahl, $\mathrm{NaOH}-\mathrm{Na}_{2} \mathrm{~S}_{2} \mathrm{O}_{3}$, butiran zink, asam borat, indikator MM, $\mathrm{HCl}$.

Alat yang digunakan dalam penelitian ini adalah baskom, timbangan, penumbuk, kompor, penggorengan, pengaduk, pisau, blender, talenan, sendok, loyang. Sedangkan alat untuk analisa antara lain timbangan analitik, alat soxlet, erlenmeyer, kertas saring, kertas lakmus, spatula, desikator, labu takar, labu kjeldahl, hotplate, thermo meter, gelas ukur, alat distilasi, cawan, oven, alat refluks, alat tanur.

\section{Rancangan Percobaan}

Penelitian menggunakan dua faktor yang disusun secara faktorial. Faktor pertama adalah varietas nangka muda yaitu nangka salak dan nangka bubur. Faktor kedua adalah proporsi tahu dengan 3 variasi yaitu $0 \%$, 20\%, 40\%. Rancangan yang digunakan adalah Rancangan Acak Kelompok (RAK). Penelitian diulang 3 kali. Data yang diperoleh dianalisis dengan analisis ragam dengan bantuan (SPSS) versi 14. Uji lanjut menggunakan uji Tukey.

\section{Pelaksanaan Penelitian}

Nangka muda (nangka bubur dan nangka salak) disortir yang berkualitas baik \pm berumur 3-4 bulan. Nangka muda dikupas kulit luarnya, dibuang bagian tengahnya dan dipotong $\pm 4-5 \mathrm{~cm}$ agar tidak terlalu tebal. Potongan nangka muda dicuci pada air mengalir dan direndam dengan air garam selama 30 menit yang berguna menghilangkan kadar tanin di dalam nangka. Setelah direndam, nangka muda dikukus kurang lebih selama 
20 menit. Nangka muda yang telah matang selanjutnya dipisahkan biji dan daging buahnya. Daging buah nangka digiling dengan penggilingan daging hingga halus (biji buah nangka dibuang). Tahu kedelai dikukus selama 10 menit. Tahu yang telah dikukus selanjutnya digiling hingga halus. Bumbu seperti, bawang putih, ketumbar, jinten, cabe merah, daun jeruk purut, gula merah, asam jawa, garam dihaluskan dengan blender. Bumbu yang sudah dihaluskan dicampur dengan bubur nangka muda dan bubur tahu kedelai. Adonan dendeng diletakkan di atas loyang dengan ukuran $30 \mathrm{~cm}$ x $30 \mathrm{~cm}$. Adonan dendeng dijemur dengan bantuan sinar matahari selama 2 hari. Potong dendeng yang telah kering \pm $1 \mathrm{~cm} \times 2 \mathrm{~cm}$. Dendeng yang sudah dipotong dilakukan analisa kadar air, kadar serat, kadar protein dan kadar abu. Sebagian dendeng yang telah dipotong digoreng $\mathrm{di}$ atas penggorengan anti lengket. Dendeng yang telah digoreng dilakukan analisa organoleptik meliputi uji rasa, aroma, warna dan tekstur.

\section{Parameter yang Diamati}

Parameter yang diamati pada dendeng TAHUNA yaitu kadar air, kadar serat, kadar protein, kadar abu, uji organoleptik meliputi rasa, aroma, warna, tekstur.

\section{HASIL DAN PEMBAHASAN}

\section{Kadar Air}

Dari pengamatan diketahui kadar air terendah pada perlakuan nangka salak dengan proporsi tahu $0 \%$ sebesar $14,3 \%$, sedangkan kadar air tertinggi pada perlakuan nangka bubur dengan proporsi tahu $40 \%$ sebesar $22,3 \%$.

Berdasarkan analisis statistik melalui anova, diperoleh bahwa tidak ada interaksi antara varietas nangka muda dan proporsi tahu terhadap kadar air dendeng TAHUNA yang dihasilkan. Sedangkan varietas nangka salak dan nangka bubur berpengaruh sangat nyata terhadap kadar air dendeng dan proporsi tahu juga berpengaruh sangat nyata terhadap kadar air dendeng yang dihasikan. Hasil rerata kadar air dendeng TAHUNA dapat dilihat pada Tabel 1 dan Tabel 2.

Berdasarkan Tabel 1. Dapat diketahui bahwa varietas nangka 
salak menghasilkan kadar air dendeng TAHUNA yang lebih rendah dibandingkan varietas nangka bubur.

Tabel 1 : Hasil Uji Rerata Kadar Air Varietas Nangka (Uji Tukey HSD)

\begin{tabular}{c|c}
\hline Jenis Nangka & $\begin{array}{c}\text { Rerata Air } \\
(\%)\end{array}$ \\
\hline $\mathrm{N}_{1}$ (Nangka Salak) & $16,818^{\mathrm{a}}$ \\
\hline $\mathrm{N}_{2}$ (Nangka Bubur) & $18,707^{\mathrm{b}}$ \\
\hline Keterangan: $\begin{array}{l}\text { Angka yang didampingi huruf } \\
\text { yang berbeda menunjukkan } \\
\text { berbeda nyata }\end{array}$
\end{tabular}

Tabel 2 : Hasil Uji Rerata Kadar Air Proporsi Tahu (Uji Tukey HSD)

\begin{tabular}{c|c}
\hline $\begin{array}{c}\text { Proporsi } \\
\text { Nangka }: \text { Tahu }\end{array}$ & $\begin{array}{c}\text { Rerata Air } \\
(\%)\end{array}$ \\
\hline $1000: 0$ gram & $15,3500^{\mathrm{a}}$ \\
\hline $800: 200$ gram & $18,0500^{\mathrm{b}}$ \\
\hline $600: 400$ gram & $21,5667^{\mathrm{c}}$ \\
\hline Keterangan: & $\begin{array}{l}\text { Angka yang didampingi huruf } \\
\text { yang berbeda } \\
\text { berbeda nyata }\end{array}$
\end{tabular}

Hal ini diduga karena varietas nangka bubur memiliki kadar air yang lebih tinggi dibandingkan kadar air varietas nangka salak. Hal ini ditunjukkan dengan daging nangka salak yang lebih berserat dan keras dibandingkan nangka bubur yang teksturnya lebih lunak.

Berdasarkan Tabel 2, bahwa semakin tinggi proporsi tahu, kadar air semakin meningkat. Hal ini dikarenakan tahu mengandung kadar air cukup tinggi sebesar 85,40\%. Pada penelitian sebelumnya menurut Erma dan Agustin (2010) tahu mempengaruhi tekstur bakso dengan semakin banyak tahu maka tekstur pada bakso menjadi lebih lunak yaitu salah satu faktor yang mempengaruhi tekstur bakso adalah kadar air tahu relatif cukup tinggi dan kandungan amilosa amilopektin penyusun pati yang rendah.

Berdasarkan pengujian kadar air, dendeng hasil penelitian sesuai dengan kriteria pangan semi basah (intermediate moisture meat product) menurut Huang dan Nip (2001). Dendeng TAHUNA memiliki kadar air yang hampir sama dengan kadar air dendeng nabati. Menurut beberapa referensi penelitian kadar air dendeng nabati, dendeng bunga pisang (Dyah, 2006) memiliki kadar air 16,63\%-16,66\%, dendeng jamur subtitusi ikan lele (Wiwin, 2012) memiliki kadar air 15,35\%-19,3\% dan menurut Suparno (1992) kadar air dendeng sebesar 15\%-20\%, menurut Sudarisma \& Elvira (1996) dendeng memiliki kadar air sebesar 20-40\%, Menurut Fachrudin (1997) dendeng memiliki kadar air sebesar 20-40\%. Sehingga 
dapat disimpulkan kadar air dendeng TAHUNA telah memenuhi syarat makanan setengah basah.

\section{Kadar Serat}

Dari pengamatan diketahui kadar serat terendah pada perlakuan nangka salak dengan proporsi tahu $40 \%$ sebesar $5,05 \%$, sedangkan kadar serat tertinggi pada perlakuan nangka bubur dengan proporsi tahu $0 \%$ sebesar $11,9 \%$.

Berdasarkan analisis statistik melalui anova, diperoleh bahwa ada interaksi antara varietas nangka muda dan proporsi tahu terhadap kadar serat dendeng yang dihasilkan. Sedangkan varietas nangka muda berpengaruh sangat nyata terhadap kadar serat dendeng dan proporsi tahu juga berpengaruh sangat nyata terhadap kadar serat dendeng yang dihasikan. Interaksi kadar serat dendeng TAHUNA dapat dilihat pada Tabel 3 dan Gambar 1.

Berdasarkan Tabel 3 dan Gambar 1, bahwa semakin banyak penambahan proporsi tahu kadar serat dendeng mengalami penurunan, sedangkan semakin sedikit penambahan proporsi tahu kadar serat dendeng mengalami peningkatan.
Hal ini karena tahu memiliki kandungan serat yang rendah yaitu 0,5 gram. Menurut Santoso (2005) tahu memiliki kadar serat sebesar 0,5 gram. Rendahnya kandungan serat di dalam tahu dikarenakan pada proses pembuatan tahu hanya menggunakan sari pati yang diendapkan, sehingga seratnya lebih banyak tersimpan pada ampasnya. Selain itu menurut Wijayanti (2018) nangka muda memiliki kadar serat yang cukup tinggi sebesar $6,46 \%$, sehingga semakin banyak penambahan nangka muda maka semakin tinggi kadar serat dendeng TAHUNA.

Tabel 3 : Hasil Rerata Kadar Serat (Uji Tukey HSD)

\begin{tabular}{l|l}
\hline \multicolumn{1}{c|}{ Perlakuan } & $\begin{array}{c}\text { Rerata Serat } \\
(\%)\end{array}$ \\
\hline $\begin{array}{l}\text { Nangka Salak : Tahu } \\
1000: 0 \text { gram }\end{array}$ & $10,0100^{\mathrm{c}}$ \\
\hline $\begin{array}{l}\text { Nangka Salak : Tahu } \\
800: 200 \text { gram }\end{array}$ & $7,1567^{\mathrm{b}}$ \\
\hline $\begin{array}{l}\text { Nangka Salak : Tahu } \\
600: 400 \text { gram }\end{array}$ & $5,0500^{\mathrm{a}}$ \\
\hline $\begin{array}{l}\text { Nangka Bubur : Tahu } \\
1000: 0 \text { gram }\end{array}$ & $11,9733^{\mathrm{d}}$ \\
\hline $\begin{array}{l}\text { Nangka Bubur : Tahu } \\
800: 200 \text { gram }\end{array}$ & $7,7467^{\mathrm{b}}$ \\
\hline $\begin{array}{l}\text { Nangka Bubur : Tahu } \\
600: 400 \text { gram }\end{array}$ & $5,2400^{\mathrm{a}}$ \\
\hline $\begin{array}{l}\text { Keterangan: Angka yang didampingi huruf } \\
\text { yang berbeda menunjukkan } \\
\text { berbeda nyata. }\end{array}$
\end{tabular}




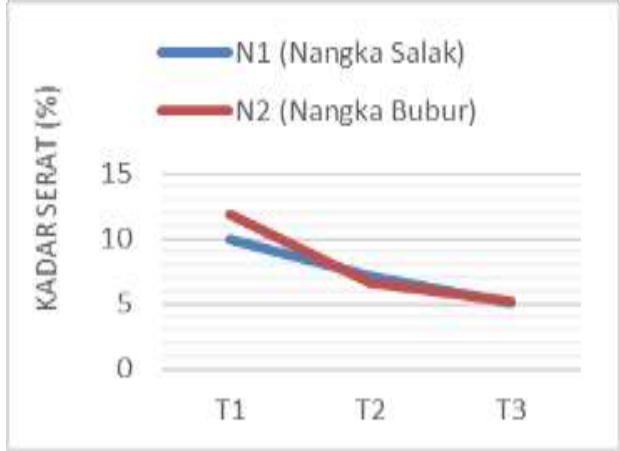

Gambar 1. Interaksi Hasil Pengujian Kadar Serat Dendeng TAHUNA

Keterangan :

Proporsi Nangka : Tahu

T1 : $1000: 0$ gram

$\mathrm{T} 2: 800: 200$ gram

T3 : $600: 400$ gram

\section{Kadar Protein}

Dari pengamatan diketahui kadar protein terendah pada perlakuan nangka salak dengan proporsi tahu $0 \%$ sebesar $4,56 \%$, sedangkan kadar protein tertinggi pada perlakuan nangka salak dengan proporsi tahu $40 \%$ sebesar $14,46 \%$.

Berdasarkan analisis statistik melalui anova, diperoleh bahwa ada interaksi antara varietas nangka muda dan proporsi tahu terhadap kadar protein dendeng yang dihasilkan. Sedangkan varietas nangka muda berpengaruh sangat nyata terhadap kadar protein dendeng dan proporsi tahu juga berpengaruh sangat nyata terhadap kadar protein dendeng yang dihasikan. Interaksi kadar protein dendeng TAHUNA dapat dilihat pada Tabel 4 dan Gambar 2.

Tabel 4 : Hasil Rerata Kadar Protein (Uji Tukey HSD)

\begin{tabular}{l|c}
\hline \multicolumn{1}{c|}{ Perlakuan } & \multicolumn{1}{c}{$\begin{array}{c}\text { Rerata } \\
\text { Protein } \\
(\%)\end{array}$} \\
\hline $\begin{array}{l}\text { Nangka Salak : Tahu } \\
1000: 0 \text { gram }\end{array}$ & $4,9033^{\mathrm{a}}$ \\
\hline $\begin{array}{l}\text { Nangka Salak : Tahu } \\
800: \text { :00 gram }\end{array}$ & $10,2433^{\mathrm{c}}$ \\
\hline $\begin{array}{l}\text { Nangka Salak: Tahu } \\
600: 400 \text { gram }\end{array}$ & $14,4633^{\mathrm{e}}$ \\
\hline $\begin{array}{l}\text { Nangka Bubur : Tahu } \\
1000 \text { gram : 0 gram }\end{array}$ & $4,5600^{\mathrm{a}}$ \\
\hline $\begin{array}{l}\text { Nangka Bubur : Tahu } \\
800: \text { 200 gram }\end{array}$ & $9,6400^{\mathrm{b}}$ \\
\hline $\begin{array}{l}\text { Nangka Bubur : Tahu } \\
600: 400 \text { gram }\end{array}$ & $12,8000^{\mathrm{d}}$ \\
\hline Keterangan: Angka yang didampingi huruf \\
\hline
\end{tabular}

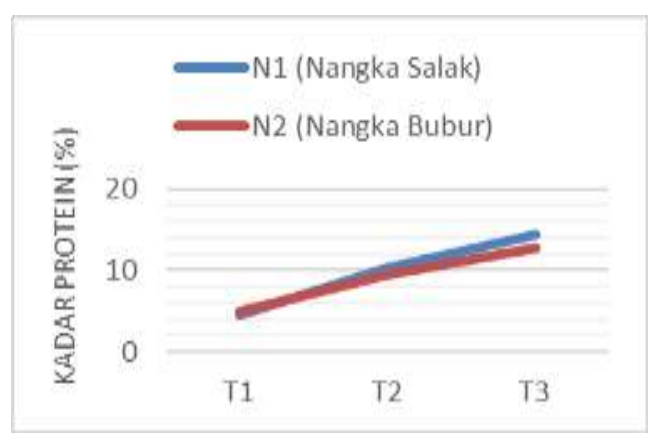

Gambar 2. Interaksi Hasil Pengujian Kadar Protein Dendeng TAHUNA

\section{Keterangan :}

Proporsi Nangka : Tahu

T1 : $1000: 0$ gram

T2 : $800: 200$ gram

T3 : 600 : 400 gram

Berdasarkan Tabel 4 dan

Gambar 2, bahwa semakin banyak 
penambahan proporsi tahu kadar protein dendeng mengalami peningkatan, sedangkan semakin sedikit penambahan proporsi tahu kadar protein dendeng mengalami penurunan. Selain itu varietas nangka juga mempengaruhi kadar protein dendeng yang dihasilkan. Hal ini karena kandungan protein pada nangka muda lebih sedikit dibanding kadar protein pada tahu. Menurut Bayuputra (2011) protein tahu sebesar 7,8 gram dan menurut Syafitri (2009) pengaruh tepung tahu mampu meningkatkan kandungan protein makanan yang dihasilkan seiring dengan meningkatnya penambahan tepung tahu terhadap produk yang dihasilkan.

\section{Kadar Abu}

Dari pengamatan diketahui kadar abu terendah pada perlakuan nangka salak dengan proporsi tahu $40 \%$ sebesar $5,11 \%$, sedangkan kadar abu tertinggi pada perlakuan nangka salak dengan proporsi tahu $0 \%$ sebesar $6,57 \%$.

Berdasarkan analisis statistik melalui anova, diperoleh bahwa tidak ada interaksi antara varietas nangka muda dan proporsi tahu terhadap kadar abu dendeng yang dihasilkan. Varietas nangka muda tidak berpengaruh nyata terhadap kadar abu dendeng, sedangkan proporsi tahu berpengaruh sangat nyata terhadap kadar abu dendeng yang dihasikan. Kadar abu dendeng TAHUNA terdapat pada Tabel 5.

Tabel 5 : Hasil Rerata Kadar Abu (Uji Tukey HSD).

\begin{tabular}{c|c}
\hline $\begin{array}{c}\text { Proporsi } \\
\text { Nangka : Tahu }\end{array}$ & $\begin{array}{c}\text { Rerata Abu } \\
(\%)\end{array}$ \\
\hline $600: 400$ gram & $5,1683^{\mathrm{a}}$ \\
\hline $800:$ 200 gram & $5,5733^{\mathrm{b}}$ \\
\hline $600: 400$ gram & $6,5083^{\mathrm{c}}$ \\
\hline $\begin{array}{c}\text { Keterangan : Angka yang didampingi huruf } \\
\text { yang berbeda menunjukkan } \\
\text { berbeda nyata. }\end{array}$
\end{tabular}

Berdasarkan Tabel 5, bahwa semakin banyak penambahan tahu dalam pembuatan dendeng TAHUNA maka kadar abu dendeng semakin turun. Sedangkan semakin banyak penambahan nangka dalam pembuatan dendeng maka kadar abu dendeng semakin meningkat. Hal ini karena tahu mengandung kadar abu cukup rendah, sedangkan menurut Nisa (2013) kadar abu nangka muda cukup tinggi yaitu sebesar 4,52\%. 


\section{Uji Organoleptik}

\section{Warna}

Dari pengamatan diketahui uji warna terendah pada perlakuan nangka salak dengan proporsi tahu $20 \%$ yaitu 3,3 (cukup), sedangkan uji warna tertinggi pada perlakuan nangka salak dengan proporsi tahu $0 \%$ yaitu 4 (suka).

Berdasarkan analisis statistik melalui anova, diperoleh bahwa tidak ada interaksi antara varietas nangka muda dan proporsi tahu terhadap organoleptik warna dendeng yang dihasilkan. Varietas nangka muda dan proporsi tahu juga tidak berpengaruh nyata terhadap organoleptik warna dendeng TAHUNA. Pada hasil pengujian organoleptik dendeng TAHUNA didapatkan warna coklat kekuningan.

Hal ini disebabkan karena adanya reaksi pencoklatan Maillard selama pengeringan dan reaksi karamelisasi selama pemanasan pada dendeng. Reaksi Maillard menghasilkan pigmen melanoidin yang menimbulkan pembentukan warna coklat dan reaksi karamelisasi menghasilkan warna coklat melalui reaksi kimia yang terjadi pada gula sederhana karena adanya proses pemanasan (Rahmawati, 2012).

\section{Aroma}

Dari pengamatan diketahui uji aroma terendah pada perlakuan nangka bubur dengan proporsi tahu 40\% yaitu 3,8 (cukup), sedangkan uji aroma tertinggi pada perlakuan nangka salak dengan proporsi tahu $0 \%$ yaitu 4,3 (suka).

Berdasarkan analisis statistik melalui anova, diperoleh bahwa tidak ada interaksi antara varietas nangka muda dan proporsi tahu terhadap organoleptik aroma dendeng yang dihasilkan. Varietas nangka muda juga tidak berpengaruh nyata terhadap organoleptik aroma den deng TAHUNA, sedangkan proporsi tahu memberikan pengaruh sangat nyata terhadap organolepik aroma dendeng yang dihasilkan. Hasil organoleptik aroma dapat dilihat pada Tabel 6 .

Berdasarkan Tabel 6, bahwa semakin banyak penambahan proporsi tahu nilai organoleptik aroma semakin menurun. Sedangkan semakin sedikit penambahan proporsi tahu nilai organoleptik aroma semakin meningkat. 
Tabel 6. Hasil Rerata Organoleptik

\begin{tabular}{c|c}
\multicolumn{2}{c}{ Aroma (Uji Tukey HSD) } \\
\hline $\begin{array}{c}\text { Proporsi } \\
\text { Nangka : Tahu }\end{array}$ & $\begin{array}{c}\text { Rerata } \\
\text { Aroma }\end{array}$ \\
\hline $600: 400$ gram & $3,85^{\mathrm{a}}$ \\
\hline $800: 200$ gram & $4,05^{\mathrm{ab}}$ \\
\hline $1000: 0$ gram & $4,25^{\mathrm{b}}$ \\
\hline Keterangan: & $\begin{array}{l}\text { Angka yang didampingi huruf } \\
\text { yang berbeda } \\
\text { berbeda nyata. }\end{array}$
\end{tabular}

Perbedaan aroma ini disebabkan karena adanya penambahan proporsi tahu dalam pembuatan dendeng TAHUNA, proporsi tahu ini membuat aroma dendeng TAHUNA kurang tajam. Hal ini diduga karena kandungan air dalam tahu, mempengaruhi aroma dendeng TAHUNA yang dihasilkan. Menurut Ashriyyah (2015) kriteria mutu inderawi aroma dendeng yaitu aroma khas dendeng. Aroma khas dendeng yang dimaksud adalah aroma bumbu rempah-rempah yang digunakan seperti ketumbar, jinten, bawang putih, gula merah, dan dendeng yang sudah kering aromanya akan semakin khas.

\section{Rasa}

Dari pengamatan diketahui uji rasa terendah pada perlakuan nangka bubur dengan proporsi tahu $40 \%$ yaitu 3,1 (cukup), sedangkan uji rasa tertinggi pada perlakuan nangka salak dengan proporsi tahu $20 \%$ yaitu 3,6 (cukup).

Berdasarkan analisis statistik melalui anova, diperoleh bahwa tidak ada interaksi antara varietas nangka muda dan proporsi tahu terhadap organoleptik rasa dendeng yang dihasilkan. Varietas nangka muda dan proporsi tahu juga tidak berpeng aruh nyata terhadap organo leptik rasa dendeng TAHUNA.

Pada pengujian organoleptik rasa dendeng TAHUNA dilakukan dengan indra pengecap yang diperoleh hasil gurih agak manis. Rasa manis tersebut dipengaruhi oleh penambahan gula merah pada proses pembuatan dendeng TAHUNAyang membuat rasa manis dendeng yang khas (Ashriyyah, 2015) dan bawang putih yang dapat memberikan rasa gurih pada makanan.

\section{Tekstur}

Dari pengamatan diketahui uji tekstur terendah pada perlakuan nangka salak dengan proporsi tahu 40\% yaitu 3,8 (cukup), sedangkan uji tekstur tertinggi pada perlakuan nangka bubur dengan proporsi tahu 0\% yaitu 4,3 (suka). 
Berdasarkan analisis statistik melalui anova, diperoleh bahwa tidak ada interaksi antara varietas nangka muda dan proporsi tahu terhadap organoleptik tekstur dendeng yang dihasilkan. Varietas nangka muda juga tidak berpengaruh nyata terhadap organoleptik tekstur dendeng TAHUNA, akan tetapi proporsi tahu memberikan pengaruh sangat nyata terhadap tekstur dendeng TAHUNA yang dihasilkan. Hasil organoleptik tekstur dapat dilihat pada Tabel 7 .

Tabel 7. Hasil Rerata Organoleptik

\begin{tabular}{c|c}
\multicolumn{2}{c}{ Tekstur (Uji Tukey HSD) } \\
\hline $\begin{array}{c}\text { Proporsi } \\
\text { Nangka }: \text { Tahu }\end{array}$ & $\begin{array}{c}\text { Rerata } \\
\text { Tekstur }\end{array}$ \\
\hline $1000: 0$ gram & $2,85^{\mathrm{a}}$ \\
\hline $800: 200$ gram & $3,85^{\mathrm{b}}$ \\
\hline $600: 400$ gram & $4,40^{\mathrm{c}}$ \\
\hline
\end{tabular}

Keterangan: Angka yang didampingi huruf yang berbeda menunjukkan berbeda nyata.

Berdasarkan Tabel 7, semakin banyak penambahan proporsi tahu tesktur dendeng TAHUNA lebih disukai karena teksturnya yang lebih lunak. Sedangkan dendeng TAHUNA tanpa adanya penambahan proporsi tahu tekstur dendeng kurang disukai karena teksturnya lebih keras.
Perbedaan tekstur ini disebabkan karena adanya penambahan proporsi tahu dalam pembuatan dendeng TAHUNA, proporsi tahu ini membuat tekstur dendeng TAHUNA semakin lunak, sedangkan tekstur dendeng tanpa adanya proporsi tahu teksturnya lebih keras. Tekstur dendeng TAHUNA yang dihasilkan adalah empuk dan berserat halus. Karakteristik nangka muda berserat halus inilah yang mempengaruhi tekstur dendeng TAHUNA. Menurut (Ashriyyah, 2015) tekstur dendeng yang baik adalah semi basah tidak terlalu kering sehingga teksturnya empuk, tidak terdapat bercak putih dan kehijauan pada permukaannya. Sedangkan bentuk dari dendeng TAHUNA adalah seperti pipihan daging yang memang sengaja untuk di bentuk menyerupai dendeng seperti pada umumnya. Menurut (SNI 01-2908-1992) dendeng merupakan makanan yang berbentuk lempengan yang terbuat dari irisan atau gilingan daging segar yang telah diberi bumbu dan dikeringkan. Bentuk dendeng yang baik adalah tipis dan lebar. Bentuk tipis dan lebar akan mempermudah proses pengeringan dendeng. 


\section{KESIMPULAN}

Dari hasil pengamatan didapatkan rata-rata kadar serat terendah $5,05 \%$ sampai tertinggi $11,9 \%$, rata-rata untuk kadar protein terendah $4,56 \%$ sampai tertinggi $14,46 \%$, rata-rata untuk kadar abu terendah $5,11 \%$ sampai tertinggi $6,57 \%$, rata-rata untuk kadar air terendah $14,3 \%$ sampai tertinggi $22,3 \%$, nilai untuk organoleptik rasa terendah 3,1 (cukup) sampai tertinggi 3,6 (cukup), nilai untuk organoleptik aroma terendah 3,8 (cukup) sampai tertinggi 4,3 (suka), nilai untuk organoleptik tekstur terendah 3,8 (cukup) sampai tertinggi 4,3 (suka) dan nilai untuk organoleptik warna terendah 3,3 (cukup) sampai tertinggi 3,8 (cukup).

Hasil analisis statistik menunjukkan varietas nangka muda memberikan pengaruh nyata terhadap kadar air, kadar serat, kadar protein. Proporsi tahu memberikan pengaruh nyata terhadap kadar air, kadar serat, kadar protein, kadar abu dan organoleptik aroma dan tekstur. Interaksi kedua faktor berpengaruh terhadap kadar serat dan kadar protein.

\section{Saran}

Disarankan penelitian lebih lanjut tentang daya simpan dan uji mikrobiologis.

\section{DAFTAR PUSTAKA}

Ashriyyah, A. 2015. Eksperimen Pembuatan Dendeng Giling Jamur Tiram (Pleurotus ostreanus) Substitusi Ikan Lele. Skripsi diterbitkan. Semarang: Universitas Negri Semarang.

Bayuputra. 2011. Perbandingan Kandungan Gizi Pada Tahu dan Ampas Tahu. http:// bayuputra.com/2011 (28 Oktober 2018).

Depkes. 1992. Komposisi Gizi Nangka dan Cempedak. Direktorat Gizi Departemen Kesehatan RI. Jakarta.

Direktorat Gizi Depkes RI. 1981. Daftar Komposisi Bahan Makanan: Jakarta.

Dyah, R. 2006. Eksperimen Pembuatan Dendeng Bunga Pisang (Musa paradisiaca). Fakultas Teknik Universitas Negeri Semarang.

Erma, H. dan S. Agustin. 2010. Analisis Kadar Zat Gizi, Uji Cemaran Logam dan Organoleptik pada Bakso dengan Substituen Ampas Tahu. Universitas Muhammadiyah Semarang. 
Nisa, T.K. 2013. Pengaruh Substitusi Nangka Muda (Artocarpus heterophyllus) terhadap Kualitas Organoleptik Nugget Ayam. Fakultas Teknik, Universitas Negeri Semarang, Indonesia.

Rahmawati, Y. 2012. Karakteristik Warna dan Mikro biologis Serta Palatabilitas Dendeng Sapi yang Diberi Perlakuan Metode Curing Berbeda. Skripsi diterbitkan. Bogor: Fakultas Peternakan Institut Pertanian Bogor.

Santoso. 2005. Teknologi Pengolahan Kedelai (Teori dan Praktek). Universitas Widyagama. Malang.

Suparno. 1992. Ilmu Dan Teknologi Daging. Universitas Gadjahmada. Yogyakarta.
Syafitri, D. 2009. Pengaruh Substitusi Tepung Ampas Tahu pada Kue Ulat Sutra terhadap Kualitas Organoleptik dan Kandungan Gizi. Universitas Negeri Semarang.

Wiwin, A. 2012. Pengaruh Perendaman Terhadap Kualitas Dendeng Ikan Lele. Universitas Negeri Semarang.

Wijayanti, R.A.I.Y, W.H Susanto, dan N. Wijayanti. 2018. Pengaruh Tingkat Kematangan Buah Nangka Bubur (Artocarpus heterophyllus) dan Proporsi Gula terhadap Karakteristik Fisik, Kimia dan Organoleptik Lempok Nangka Bubur. Universitas Brawijaya Malang. 